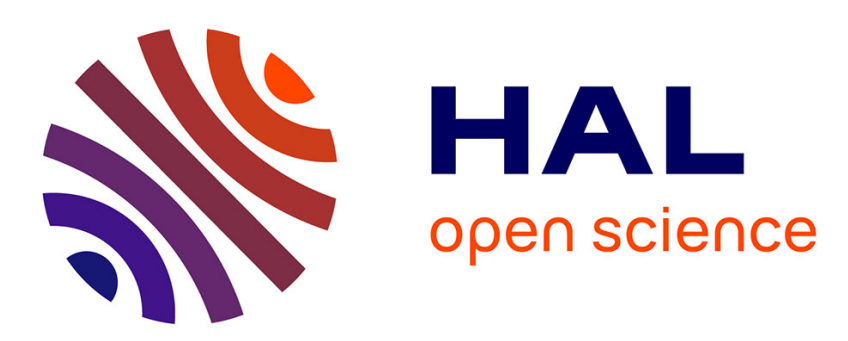

\title{
Invasive rat space use on tropical islands: implications for bait broadcast
}

\author{
David Ringler, James C. Russell, Audrey Jaeger, Patrick Pinet, Matthieu \\ Bastien, Matthieu Le Corre
}

\section{- To cite this version:}

David Ringler, James C. Russell, Audrey Jaeger, Patrick Pinet, Matthieu Bastien, et al.. Invasive rat space use on tropical islands: implications for bait broadcast. Basic and Applied Ecology, 2014, 15 (2), pp.179-186. hal-01306711

\section{HAL Id: hal-01306711 https://hal.univ-reunion.fr/hal-01306711}

Submitted on 26 Apr 2016

HAL is a multi-disciplinary open access archive for the deposit and dissemination of scientific research documents, whether they are published or not. The documents may come from teaching and research institutions in France or abroad, or from public or private research centers.
L'archive ouverte pluridisciplinaire HAL, est destinée au dépôt et à la diffusion de documents scientifiques de niveau recherche, publiés ou non, émanant des établissements d'enseignement et de recherche français ou étrangers, des laboratoires publics ou privés. 


\title{
Invasive rat space use on tropical islands: Implications for bait broadcast
}

\author{
David Ringler ${ }^{\mathrm{a}, *}$, James Russell ${ }^{\mathrm{b}}$, Audrey Jaeger ${ }^{\mathrm{a}}$, Patrick Pinet ${ }^{\mathrm{a}}$, \\ Matthieu Bastien ${ }^{\mathrm{a}}$, Matthieu Le Corre ${ }^{\mathrm{a}}$ \\ a Laboratoire d'Ecologie Marine, Université de la Réunion, 15 av René Cassin, 97744 Saint Denis, France \\ ${ }^{\mathrm{b}}$ School of Biological Sciences and Department of Statistics, University of Auckland, Private Bag 92019, Auckland, \\ New Zealand
}

\begin{abstract}
Invasive rats on oceanic islands impact a large number of native species. Control programmes, and in many cases complete eradication, are used to alleviate these impacts. Basic data on rodent biology facilitate the design of control or eradication programmes, and is particularly required for programmes on tropical islands where such data are missing. Here we test for interactive effects of habitat and season that may alter black rat (Rattus rattus) space use dynamics and inform rodent management on two tropical islands. Five years of summer and winter trapping data were analysed using spatially explicit capture-recapture to calculate rat space-use and overlap, coupled with spool and line experiments ground-truthing microhabitat use. Variation in individual rat space use is primarily driven by sex and bottom-up trophic effects of seasonal rainfall on food resources, but is altered by island-specific contexts. In the absence of other introduced mammals, rats tend to have stable range overlap throughout the year but home range sizes fluctuate seasonally with rat density. The presence of other introduced mammals causes predictable greater seasonal fluctuations in rat space-use, putatively a behavioural adjustment to feral cats (Felis catus) diet-switching to rats from seasonal influxes of their alternative seabird prey. We identify winter as the recommended treatment period on both islands and discuss bait broadcast strategies.
\end{abstract}

\section{Zusammenfassung}

Invasive Ratten beeinträchtigen auf ozeanischen Inseln eine große Anzahl von einheimischen Arten. Kontrollprogramme und in vielen Fällen die vollständige Ausrottung werden genutzt, um diese Beeinträchtigungen zu mildern. Grundlegende Daten zur Kleinsäugerbiologie erleichtern die Planung von Kontroll- und Ausrottungsprogrammen. Sie werden besonders für Programme auf tropischen Inseln benötigt, wo solche Daten fehlen. Hier untersuchen wir die Interaktionen zwischen Habitat und Jahreszeit, die die Raumnutzung von Hausratten (Rattus rattus) verändern und dem Kleinsäugermanagement zugrunde gelegt werden können. Sommer- und Winterfallenfänge aus fünf Jahren mit räumlich explizitem Fang/Wiederfang wurden analysiert, um Raumnutzung und Überlappung der Ratten zu berechnen. Mit der Fadenspulen-Methode wurden Vergleichsmessungen zur Mikrohabitatnutzung durchgeführt. Die Variation der Raumnutzung durch Rattenindividuen wird in erster Linie vom Geschlecht und den durch saisonale Regenfälle bedingten Nahrungsressourcen bestimmt; sie wird aber durch inselspezifische Zusammenhänge modifiziert.

\footnotetext{
*Corresponding author. Tel.: +262 262938689 ; fax: +262 262938685 .

E-mail address: david.ringler@univ-reunion.fr (D. Ringler).
} 
Wenn keine anderen eingeführten Säuger vorhanden sind, ist die Überlappung der Territorien über das Jahr hinweg tendenziell stabil, aber die Größe der Aktionsräume schwankt saisonal mit der Rattendichte. Die Anwesenheit anderer eingeführter Säuger ist mit vorhersagbaren, größeren saisonalen Schwankungen der Raumnutzung durch die Ratten verbunden-vermutlich eine verhaltensbedingte Anpassung an den saisonal bedingten Nahrungswechsel verwilderter Hauskatzen (Felis catus) vo $\mathrm{n}$ Seevögeln, ihrer alternativen Beute, hin zu Ratten. Wir fanden heraus, dass auf beiden Inseln der Winter die zu empfehlende Behandlungszeit ist, und diskutieren verschiedene Köderausbringungsstrategien.

Keywords: Rattus rattus; Spatially explicit capture-recapture; Spool and line; Home range; Overlap; Microhabitat use; Eradication

\section{Introduction}

Invasive rats (Rattus exulans, $R$. norvegicus \& $R$. rattus) have been introduced to most archipelagos in the world from polar to tropical islands (Atkinson 1985). Their adverse impacts on biodiversity through direct consumption (Jones, Tershy, Zavaleta, Croll, \& Keitt 2008) or synergic indirect effects (Russell 2011) have been well documented and have been proven to be very persistent (Bourgeois, Ouni, Pascal, Dromzée, \& Fourcy 2013). Their capacity to cause detrimental effects on native fauna and flora is a consequence of their ability to adapt their biology to novel environments. Particularly, rats introduced on oceanic islands can adapt their body size, their breeding strategy or their diet to the island characteristics (e.g. climate, weather patterns, habitats, community structure) (Russell, Ringler, Trombini, \& Le Corre 2011). This plasticity might also be reflected by adaptive space use strategies.

Several studies have investigated the space use dynamics of invasive rodents, usually in mainland temperate environments, which have provided biological information on rat movements either in a single specific location or at limited spatio-temporal scales (Dowding \& Murphy 1994; Cox, Dickman, \& Cox 2001). Methods have generally used expensive and time-consuming radio telemetry experiments that prevented tests for complex environmental effects (e.g. individual covariates, season, habitat, site) on ranging dynamics. Particularly little is known about interactions between weather patterns and island community structure on rat spatial ecology. From a conservation perspective, biological data on rat space use - their home ranges, the distances they move, their aggregation and their preferred microhabitat features are essential to provide guidelines for the design of control and eradication strategies (Hooker \& Innes 1995).

Eradication techniques to restore invaded islands have considerably improved from bait stations and hand broadcast of toxic bait to aerial broadcast of bait-delivered anticoagulants (Howald et al. 2007). Spatial patterns in bait delivery occur during broadcast, but whereas optimal spacing in bait broadcast or between stations leads to efficient use of bait, gaps may lead to reduced control efficacy or even eradication failure, such as when space between bait lines or stations exceeds minimal rat home range (Morgan 2004).

In this study we investigate rat movements and home ranges on two tropical Indian Ocean islands and use the findings to supply information to tropical eradication managers. The study first aimed to test contributions of intrinsic and environmental parameters on rat space use dynamics, and the consistency of any such effects between islands. We used live trapping experiments to produce a large and robust spatio-temporal dataset of tropical rat home range and measures of home range overlap. Within individual home ranges, we also aimed to determine whether rats range uniformly within the total space they use or if they differentially use parts of their home range. For this purpose we compared results from daily movement and simulated home range sizes. Finally, for each island we looked at what could be the recommended treatment period and conservative bait gap threshold, i.e. the maximum tolerable distance between bait broadcast or stations of baits to ensure all rats rapidly encounter baits. For each combination of island and habitat we used the smallest home range scenario depending on age and sex of the rats but also according to season.

\section{Materials and methods}

\section{Study sites}

The study was conducted on Europa and Juan de Nova, two coralline atolls lying in the south-western Indian Ocean between East Africa and Madagascar. Both islands are French overseas territories located in the Mozambique Channel (Fig. 1), part of the Iles Eparses and under the authority of the Terres Australes et Antarctiques Françaises (TAAF). Europa $\left(2223 \mathrm{ha}, 22^{\circ} 21^{\prime} \mathrm{S}, 40^{\circ} 21^{\prime} \mathrm{E}\right)$ is a relatively undisturbed island and a major breeding site for eight seabird species (ca. 1 million pairs) as well as green turtles. Black rats and goats (Capra hircus) are the only two introduced mammals present on the island. Juan de Nova (561 ha, $17^{\circ} 03^{\prime} \mathrm{S}, 42^{\circ} 45^{\prime} \mathrm{E}$ ) was mined for guano and holds the largest sooty tern (Onychoprion fuscatus) colony of the south-western Indian Ocean with approximately two million pairs. Black rats coexist with introduced cats (Felis catus) (estimated at around 60 individuals) and mice (Mus musculus). On both islands, climate is semi-arid with a warm and wet season during the austral summer (November-April) and a dry season during the cooler austral winter (May-October). 


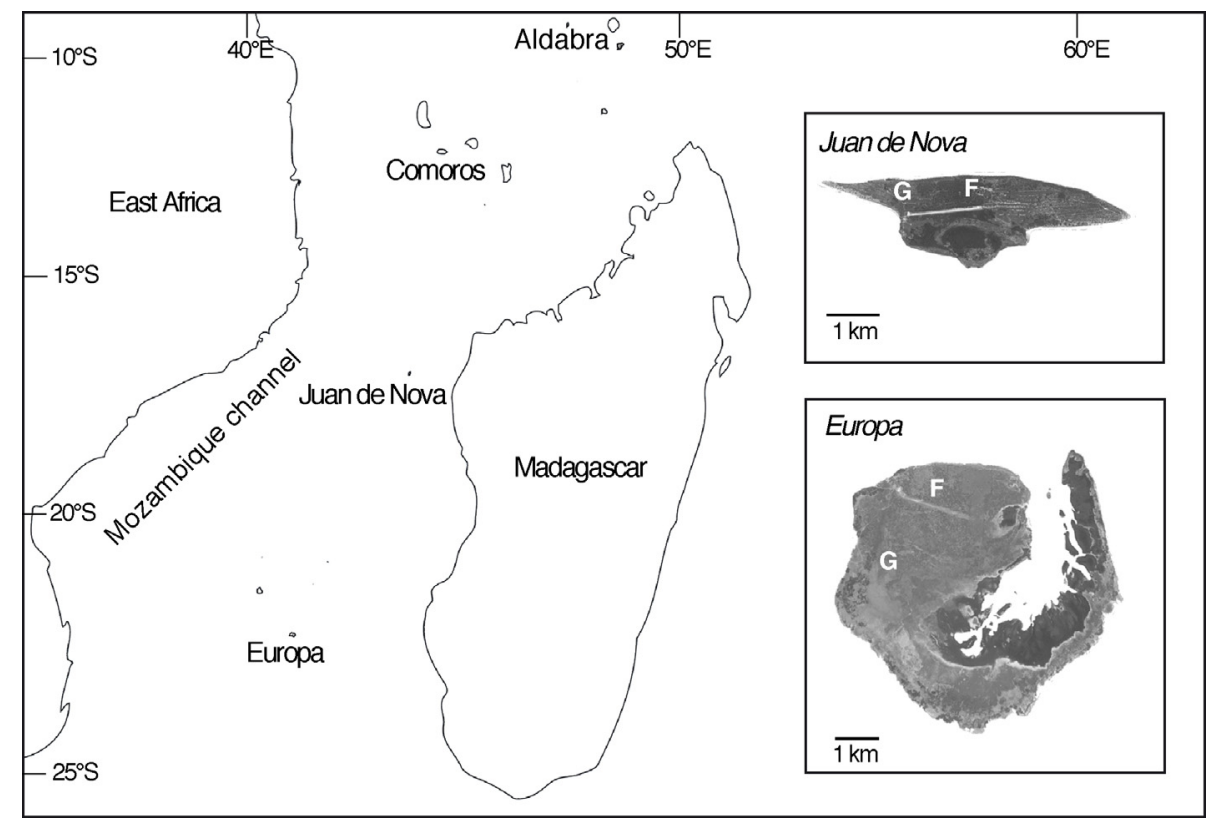

Fig. 1. Map of study sites and locations of sampled forest habitat (F) and grassland habitat $(\mathrm{G})$.

\section{Sampling}

Black rats were live-trapped on both islands during the summer and winter between February 2008 and December 2012. Mark-recapture sessions were conducted on each island in two different types of habitat; tropical dry forest (Euphorbia stenoclada, Casuarina equisetifolia) and grassland (Sclerodactylon macrostachyum, Poaceae). During each session, 49 wire traps (BTTM Mécanique, Besançon, France) were set following a $7 \times 7$ grid at $10 \mathrm{~m}$ spacing $(0.36 \mathrm{ha})$. For ten consecutive days (10 occasions), each trap was baited and set in the evening $(5 \mathrm{pm})$ and checked the next morning ( 7 am). Rats captured for the first time were sexed, weighed, ear-tagged and released. We recorded the tag number and location on the grid of each recapture event.

\section{Home range and movements}

Home range has been related to the extent of area with a defined probability of occurrence of an animal during a specified time period (Horne \& Garton 2006). Thus home range radius may be confounded with distance from home range centre (scale parameter of a detection function) when the probability of capture of an individual approaches 0 . Spatially explicit capture-recapture (SECR) analysis enables determination of probability of detection of an individual as a function of distance from an assumed home range centre, if the spatial pattern of the home range centres is known. We assumed that home ranges are circular and their centres follow a homogeneous Poisson distribution and that, for the duration of trapping, the location of each individual in the population may be summarised by the coordinates of a point that we call the rat's home range centre. For the spatially explicit capture probability model we assumed a hazard-rate function defined by three parameters, $g 0$ (probability of capture at the home range centre), $\sigma$ (scale parameter) and the shape parameter $z$, with sex and age as individual covariates and season, habitat and island as session covariates. Individual capture histories were implemented with R package 'secr' (Borchers \& Efford 2008; Efford, Borchers, \& Byrom 2009). The three model parameters were estimated using conditional maximum-likelihood on covariates. Different sub-models were tested to determine whether covariates had an effect on the scale parameter sigma. Each model was considered a competing best model when $\mathrm{dAIC}_{\mathrm{c}}<2$. Using a circular hazard distribution we calculated the $95 \%$ and the $50 \%$ probability density area of detection as surrogates for black rat home range $\left(\mathrm{HR}_{95}\right)$ and home range core area $\left(\mathrm{HR}_{50}\right)$ :

$$
\begin{aligned}
& \mathrm{HR}_{95}=\pi \times(3.36 \times \sigma)^{2} \\
& \mathrm{HR}_{50}=\pi \times(1 \times \sigma)^{2}
\end{aligned}
$$

\section{Density and overlap}

Capture-recapture data were also used to determine probability density functions for the estimated locations of the home range centres. Modes of these functions were assumed to be individual home range centres. For each individual, home range contour, calculated from home range centre and $\mathrm{HR}_{95}$ radius, was transformed to a spatial polygon. For each $10 \mathrm{~m} \times 10 \mathrm{~m}$ unit of the sampling grid $(60 \mathrm{~m} \times 60 \mathrm{~m})$ we calculated an overlap index of individual home ranges defined as the number of different overlapping individual polygons. We used a Poisson-error generalised linear model to test any effect of habitat type, season and island on maximum overlap 
Table 1. Model results of black rat detection function for covariates of the scale parameter (sigma) and the probability of capture at the home range centre $(\mathrm{g} 0)$.

\begin{tabular}{|c|c|c|c|c|c|c|}
\hline g0 & Sigma & Npar & Log likelihood & $\mathrm{AICc}$ & Rank & $\%$ Weight \\
\hline$\sim$ Season + sex + age & $\sim$ Sex + habitat + season $\times$ island & 11 & -9590.34 & 19203.09 & 1 & 54.2 \\
\hline$\sim$ Season + sex + age & $\sim$ Habitat + season $\times$ island & 10 & -9592.39 & 19205.13 & 2 & 19.4 \\
\hline$\sim$ Season + sex + age & $\sim$ Sex + age + habitat + season $\times$ island & 12 & -9590.33 & 19205.16 & 3 & 19.2 \\
\hline$\sim$ Season + sex + age & $\sim$ Age + habitat + season $\times$ island & 11 & -9592.36 & 19207.13 & 4 & 7.2 \\
\hline
\end{tabular}

index (i.e. highest value of overlap index for each sampling session).

\section{Spool line}

In order to ground-truth our home range models during spring 2011 (October-November), the daily tracks of rats on both islands were monitored using a spool-and-line technique to assess daily movements and space use of black rats in the forest and grassland macrohabitats. In the morning, livetrapped black rats were equipped with nylon cocoons (NWB nylon \#7, Cansew Inc., Montreal, Canada) wrapped into duct and masking tape (Vieira, Iob, Briani, \& Palma 2005). This device $(2.5 \mathrm{~g}$, thread length $=215 \mathrm{~m}$ ) was attached to the shaved back of the rat using ester-cyanoacrylate-based glue. Rats were sexed, weighed and then immediately released to limit stress behaviour. One end of the thread was tied to the trap before the release of the rat. The next morning, that is approximately $24 \mathrm{~h}$ after release, the line was collected and mapped using a compass. The trip made by the rat was split into different segments. We considered a new segment in the path each time we had a minimum 5-degree azimuth change or a modification in the type of microhabitat substrate used by the rat. Lengths of the individual collected segments of the path were measured afterwards. The substrate associated with each segment of the path was noted as well as the presence of den sites or food hoarding sites. Significant differences in macrohabitat and microhabitat feature use between islands were tested for with a log-linear model of distance traversed counted in metres, specifically testing for interactions of macrohabitat or microhabitat use with island. This accounted for a priori expected relationships between macrohabitat and microhabitat abundance and track lengths differing between islands and macrohabitats. The completed routes were used to estimate the daily movement area of rats by constructing the minimum convex polygon (MCP) containing $100 \%$ of the data. We discarded the first $10 \mathrm{~m}$ from the analysis as flight response.

\section{Results}

\section{Home range and movements}

The best SECR model had 54.2\% support and included effects of sex, season and habitat type on the shape parameter $\sigma$ of the detection function (Table 1). Female home ranges were found to be smaller than male rat home ranges. For both sexes home ranges were also smaller in forest than in grassland (Table 2). HR95 estimates ranged from 0.348 to 0.839 ha in forest and from 1.274 to 3.076 ha in grassland. The effect of season depended on island (Table 2). Home ranges increased from summer to winter on Europa, whereas they decreased on Juan de Nova, although they were on average larger on Juan de Nova than Europa (Fig. 2).

Rats mean maximum distance moved (MMDM) calculated as maximal distances between captures were also habitat dependent but they tended to be smaller than estimated home range width (i.e. $2 \times 3.36 \times \sigma$ ). MMDM ranged from $25.8 \pm 4.4 \mathrm{~m}$ in forest to $35.6 \pm 6.9 \mathrm{~m}$ in grassland, whereas mean home range diameters were $80.3 \pm 13.3 \mathrm{~m}$ in forest

Table 2. Estimates of the beta parameters for the best SECR model with standard error and 95\% confidence interval (lower class and upper class).

\begin{tabular}{|c|c|c|c|c|}
\hline Beta parameter & Estimate & SE & $\mathrm{lcl}$ & $\mathrm{ucl}$ \\
\hline g0 & -1.53 & 0.10 & -1.74 & -1.32 \\
\hline g0.season (winter) & 0.33 & 0.10 & 0.13 & 0.54 \\
\hline g0.sex (male) & -0.29 & 0.10 & -0.49 & -0.10 \\
\hline g0.age (juvenile) & -0.06 & 0.08 & -0.24 & 0.11 \\
\hline$\sigma$ & 2.30 & 0.05 & 2.20 & 2.40 \\
\hline$\sigma \cdot \operatorname{sex}($ male $)$ & 0.08 & 0.04 & 0.00 & 0.18 \\
\hline$\sigma$. habitat (grassland) & 0.64 & 0.06 & 0.52 & 0.77 \\
\hline$\sigma$. season (winter) & 0.16 & 0.05 & 0.06 & 0.26 \\
\hline$\sigma$. island (Juan de Nova) & 0.34 & 0.07 & 0.22 & 0.47 \\
\hline$\sigma$. season (winter):island (Juan de Nova) & -0.51 & 0.09 & -0.69 & -0.34 \\
\hline
\end{tabular}



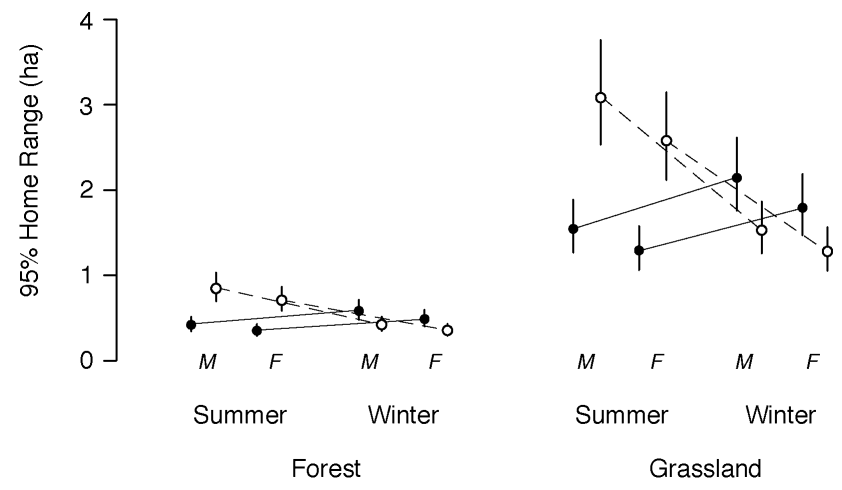

Fig. 2. $95 \%$ home range estimates and $95 \%$ confidence intervals (bars) of male (M) and female (F) black rats from Europa (black dots and straight lines) and Juan de Nova (white dots and dashed lines) in forest and grassland.

and $153.8 \pm 25.5 \mathrm{~m}$ in grassland. The MCP areas of rats' daily trips, estimated by spool-and-line tracking, accounted for $5.1-12.1 \%$ of the estimated theoretical home ranges $\left(\mathrm{HR}_{95}\right.$, i.e. radius $\left.=3.36 \sigma\right)$ on Europa and $6.6-11.1 \%$ in Juan de Nova. However the MCP areas of the spool lines were consistent with home range core area estimates $\left(\mathrm{HR}_{50}\right.$, i.e. radius $=\sigma$ ) as indicated by ratios of $57.2-136.9 \%$ on Europa and $74.5-124.9 \%$ on Juan de Nova (Table 3).

\section{Overlap}

The minimal adequate generalised linear model indicated that maximum overlap of rats' home ranges per sampling session was significantly affected by habitat type (Table 4). Maximum number of overlapping home ranges was larger in forest (Fig. 3). The number of overlapping home ranges also differed between seasons and was dependent on island (Table 4), although on average there was no significant difference between seasons or islands. Overlap decreased two-fold between summer and winter on Juan de Nova, whereas it remained nearly constant on Europa (Fig. 3). Maximum overlap recorded was 41 home ranges per sampling grid unit $\left(100 \mathrm{~m}^{2}\right)$ in forest (Europa, summer 2008) and 27 home ranges per $100 \mathrm{~m}^{2}$ in grassland (Juan de Nova, summer 2008) (Fig. 3).

\section{Microhabitat use}

There were significant differences in macrohabitat and microhabitat use between islands (Table 5). Ground and shrub

Table 3. Trip lengths, minimum convex polygon (MCP) and proportion of total home range $\left(\mathrm{HR}_{95}\right)$ and home range core area $\left(\mathrm{HR}_{50}\right)$ represented by MCP. Data are derived from the spool and line experiment in winter 2011 on Europa and Juan de Nova.

\begin{tabular}{|c|c|c|c|c|c|c|c|c|c|}
\hline \multirow[t]{2}{*}{ Island } & \multirow[t]{2}{*}{ Habitat } & \multirow[t]{2}{*}{ Sex } & \multirow[t]{2}{*}{$N$} & \multicolumn{2}{|c|}{ Length (m) } & \multicolumn{2}{|c|}{ MCP (ha) } & \multicolumn{2}{|l|}{$\% \mathrm{HR}$} \\
\hline & & & & Mean & Range & Mean & Range & $\% \mathrm{HR}_{95}$ & $\% \mathrm{HR}_{50}$ \\
\hline \multirow[t]{3}{*}{ Europa } & \multirow[t]{2}{*}{ Forest } & M & 3 & 143 & $98-192$ & 0.071 & $0.016-0.137$ & 12.1 & 136.9 \\
\hline & & $\mathrm{F}$ & 6 & 115 & $63-152$ & 0.033 & $0.003-0.129$ & 6.7 & 76.1 \\
\hline & Grassland & $\mathrm{F}$ & 3 & 136 & $95-179$ & 0.091 & $0.013-0.182$ & 5.1 & 57.2 \\
\hline \multirow[t]{4}{*}{ Juan de Nova } & \multirow[t]{2}{*}{ Forest } & M & 2 & 118 & $71-167$ & 0.046 & 0.019-0.074 & 11.1 & 124.9 \\
\hline & & $\mathrm{F}$ & 7 & 90 & $63-171$ & 0.026 & $0.011-0.061$ & 7.5 & 84.3 \\
\hline & \multirow[t]{2}{*}{ Grassland } & M & 1 & 170 & - & 0.106 & - & 7.0 & 78.6 \\
\hline & & $\mathrm{F}$ & 1 & 158 & - & 0.084 & - & 6.6 & 74.5 \\
\hline
\end{tabular}

Table 4. GLM results after model simplification (minimal adequate model) of maximum overlap index (number of overlapping rat home ranges per $100 \mathrm{~m}^{2}$ ).

\begin{tabular}{lcccc}
\hline Parameter & Estimate & SE & $Z$ & $P$-value \\
\hline Intercept & 3.53 & 0.09 & 38.14 & $<.70$ \\
Season (winter) & 0.09 & 0.12 & -3.43 & 0.483 \\
Habitat (grassland) & -0.48 & 0.14 & -1.85 & $<0.001^{* * * *}$ \\
Island (Juan de Nova) & -0.25 & 0.14 & -1.52 & 0.064 \\
S(w) $\times$ H(g) & -0.29 & 0.19 & 3.89 & 0.128 \\
S(w) $\times$ I(j) & -0.78 & 0.20 & $<.001^{* * *}$ \\
\hline
\end{tabular}

\footnotetext{
**** Highly significant
} 


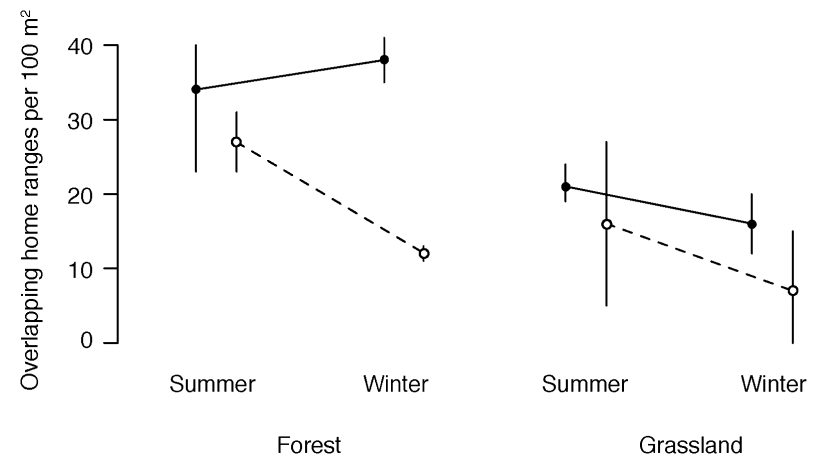

Fig. 3. Seasonal variations of mean maximum number of overlapping rat home ranges with extreme values (bars), on Europa (black dots and straights lines) and Juan de Nova (white dots and dashed lines).

were preferred microhabitats regardless of macrohabitat or island (all $p<0.001$ ). Forest dwelling rats used trees significantly more on Juan de Nova, and shrubs significantly more on Europa (all $p<0.01$ ). On Juan de Nova grassland rats also tended to use more shrub and less open ground compared to Europa grassland (all $p<0.001$ ).

\section{Discussion}

Our mark-recapture study conducted twice a year over five years provided a substantial dataset to test for complex environmental effects which may alter rat space use on tropical islands. In particular, we were able to test for higher order interactions among variables, such as the consistency of sex, habitat and season effects across both islands. We were also able to compare various statistical measures of range use, including multiple measures derived from our capture-recapture data (the $95 \%$ and $50 \%$ areas of the SECR detection function and the MMDM) and independent estimates derived from tracking a subset of rats using spool-and-line.

\section{Space use dynamics}

Previous studies have shown that rat home range size may vary due to a large number of factors including sex of individuals, population density, food availability and population breeding cycle (Innes \& Skipworth 1983; Hooker \& Innes 1995; Low, Mills, Algar, \& Hamilton 2013). On tropical islands rat dynamics are primarily driven by bottom-up effects with summer high densities associated with seasonal pulses of rainfall (Harris \& Macdonald 2007; Russell et al. 2011). Increasing home range size during winter on Europa supports the hypothesis that home range size is primarily limited by conspecific interactions (i.e. rat density). This hypothesis is reinforced by the observed differences in home range size between islands. Lower densities in grassland (Russell et al. 2011) and consequent lower intraspecific interactions resulted in overall larger home ranges for both sexes regardless of season or island.

However, previous work on interspecific interactions on these islands (Russell et al. 2011) also found that rat dynamics may also be altered by top-down effects (e.g. cat predation), enforcing elongated breeding seasons and seasonal density collapses. In the same way, seasonal variations in home range size and increased use by rats of forest trees on Juan de Nova are likely to be driven by the presence of other invasive mammals including cats and mice. We suggest that the contrasting results observed between the two islands here are consistent with an adaptive behavioural response of rats when coexisting with other introduced mammals. Indeed cats on Juan de Nova display a dietary shift switching from a seabirdbased diet during summer (i.e. sooty tern breeding season) to rat-based diet in winter (Peck, Faulquier, Pinet, Jaquemet, \& Le Corre 2008). This summer decrease in predation pressure might induce a behavioural response resulting in an increase in home range size and higher use of open ground, as has been demonstrated with other rodent species (Strauss, Solmsdorff, Pech, \& Jacob 2008). This was also reflected by the seasonal

Table 5. Microhabitat use by rats (in metres) from spool and line experiment pooled over habitat (forest vs. grassland) and island. Values stand for cumulative distance of all individual trips for each combination of microhabitat and macrohabitat structure.

\begin{tabular}{llcrrr}
\hline Microhabitat & \multicolumn{2}{l}{ Forest } & & \multicolumn{2}{l}{ Grassland } \\
\cline { 2 - 5 } & Europa & Juan de Nova & & Europa & 10 \\
Tree & 101 & 131 & 0 & 230 \\
Ground & 920 & 569 & 5 & 12 & 218 \\
Shrub & 148 & 113 & 0 & 7 \\
Dead trunk & 105 & & & 07 \\
\hline
\end{tabular}


decrease in the number of overlapping home ranges in the absence of cats' native prey (i.e. seabirds) on Juan de Nova, whereas in the absence of such seasonal variation in predation pressure, overlap remained constant on Europa.

We found significant differences in home range size between male and female rats, which confirms that eradication planners should consider home range size of female rats to determine the maximum tolerable bait spacing on the ground. Overall space-use and behaviour of rats was more variable on the island where they coexisted with other introduced mammals, which suggests eradications of rats on tropical islands must consider the wider ecological context of other introduced species.

\section{Range scales}

Different rat tracking methods provide distinctive information on rat space use scales. The $\mathrm{HR}_{95}$ values from SECR modelling used as estimators for total area ranged by rats (pooled over individuals) are consistent with previous home range studies on tropical islands using radio-tracking and other live-trapping methods (Low et al. 2013). Basic statistics on maximum range extent (MMDM) derived from trapping distances confirmed a habitat effect on distances moved by rats although they clearly underestimate total rat home range and could not supply useful information on true range boundaries.

Measurements of daily movement rates with spool-andline tracking all predicted areas that were less than $\mathrm{HR}_{95}$ (total area), and closer to $50 \%$ probability of detection home ranges $\left(\mathrm{HR}_{50}\right)$. At the time-scale of the sampling sessions (10 days) our findings support the hypothesis that rats are familiar with regions larger than the area they regularly cover to fulfil their vital functions (Cowan 1983; Bovet 1992). When determining a gap threshold, the region outside the $\mathrm{HR}_{50}$ should then be considered carefully as rats might infrequently visit it within the short time-scale ( $<4$ days) required for successful bait uptake in competition with other species (e.g. crabs) on many tropical islands.

\section{Management recommendations}

Seasonality in rodent population dynamics is currently one of the strongest considerations in planning eradication operations; a legacy from eradication planning in highly seasonal temperate environments such as New Zealand (Howald et al. 2007).

Despite season having a consistent effect across Europa and Juan de Nova on rat densities, which are lowest in winter (Russell et al. 2011), the effect of season on space use was opposite on each island. This contrast appeared to be strongly driven by context-specific characteristics of each island, which in this case was the presence of other introduced mammals and the seasonal influx of seabirds on Juan de Nova. This leads us to suggest that on tropical islands timing of poisoning treatment periods may have to be made on a case-by-case basis, at least until studies from other islands can provide additional data on global trends in rat space use.

Winter is most strongly supported for an eradication attempt on Europa. Although the overlap index indicates similar numbers of rat home ranges per unit area, densities are overall lower and there is a very low level of recruitment (Russell et al. 2011), which is considered a desirable requirement for undertaking eradication. Winter is also when rat home ranges are largest, which minimises the risk of rats not encountering baits from larger sowing gaps.

On Juan de Nova the choice of treatment period is less clear. In winter low home range overlap and densities contribute to decreasing intraspecific bait competition, but in summer larger home ranges mean larger bait spacing can be tolerated, although rats may take longer time to encounter baits. Important context-specific externalities include the massive influx of sooty terns ( 2 million pairs) and high cyclone risk during summer, which would complicate and frustrate any eradication attempt. On the weight of evidence we would also recommend rat eradication on Juan de Nova in winter, but would suggest that any eradication would need to target cats and mice at the same time so as to minimise the complications of interspecific interactions, and maximise conservation returns for economic investment.

Using $\mathrm{HR}_{95}$ estimates instead of conservative $\mathrm{HR}_{50}$ estimates to define maximum bait spacing would likely result in eradication failure. Under the latter scenario the time before rats encounter sufficient baits for a lethal dose would increase and ultimately would prevent some rats from encountering and consuming sufficient bait due to possible rat hoarding behaviour (intraspecific competition) (Morriss, Warburton, Cross, \& Nugent 2011) or high bait competition with land crabs (interspecific competition) (Wegmann, Buckelew, Howald, Helm, \& Swinnerton 2011).

Finally, our ground-truthing of rat microhabitat feature use provides evidence for rejecting the hypothesis that on Europa and Juan de Nova local rat suppressions in forest might fail because rats spend proportionally more time above ground where they cannot access baits on the ground. Our estimates of rat use of trees and shrubs on both islands $(<20 \%)$ do not differ from those of the same rat species in temperate forests of New Zealand (Dowding \& Murphy 1994), and thus we do not see the need on either island for any specific sowing in the forest habitat canopy. However, on Europa substantial mangrove inlets are present within which we did not undertake any studies of space use, and how these would be treated remains a major challenge to any rat eradication.

\section{Conclusion}

This study demonstrates how basic rodent biology may depend on combinations of individual traits (i.e. sex), island community structure, habitat heterogeneity, and season. These findings can be used to assist eradication planning, although the final choice of timing and of setting 
an acceptable gap threshold will also depend on other factors not considered in this study. In particular adjustments in any eradication plan must accommodate logistical or island specific factors. Understanding both target pest species dynamics and other island specific features is a key issue to adjust baiting methods for more cost-effective restoration efforts. Ongoing optimisation of bait sowing practices through toxin reduction remains an important challenge for future tropical island rat eradication programmes, and will play an important role towards increasing the number and maximum size of rodent-free islands.

\section{Acknowledgements}

D. Ringler benefited from a Ph.D. grant given by the Région Réunion and the European Social Fund. This research is part of the 'ALIENS' programme funded by ANR, 'Ecosystèmes Tropicaux' programme funded by MEDD and 'MIRE' programme funded by INEE. Thanks to TAAF for authorisation to work on Juan de Nova and Europa. We thank Araceli Samaniego and two anonymous referees for comments on a draft version of the manuscript.

\section{References}

Atkinson, I. (1985). The spread of commensal species of Rattus to oceanic islands and their effects on island avifaunas. In P. J. Moors (Ed.), Conservation of island birds (pp. 35-81). Cambridge: International Council for Bird Preservation Technical Publication No. 3.

Borchers, D. L., \& Efford, M. G. (2008). Spatially explicit maximum likelihood methods for capture-recapture studies. Biometrics, 64, 377-385.

Bourgeois, K., Ouni, R., Pascal, M., Dromzée, S., Fourcy, D., et al. (2013). Dramatic increase in the Zembretta Yelkouan shearwater breeding population following ship rat eradication spurs interest in managing a 1500-year old invasion. Biological Invasions, 15, 475-482.

Bovet, J. (1992). Mammals. In F. Papi (Ed.), Animal homing (pp. 321-361). Dordrecht: Springer Netherlands.

Cowan, P. E. (1983). Exploration in small mammals: Ethology and ecology. In J. Archer, \& L. I. A. Birke (Eds.), Exploration in animals and humans (pp. 147-175). Cambridge: Van Nostrand Reinhold.

Cox, M. P. G., Dickman, C. R., \& Cox, W. G. (2001). Use of habitat by the black rat (Rattus rattus) at North Head, New South Wales: An observational and experimental study. Austral Ecology, 25, 375-385.

Dowding, J. E., \& Murphy, E. C. (1994). Ecology of ship rats (Rattus rattus) in a kauri (Agathis australis) forest in Northland, New Zealand. New Zealand Journal of Ecology, 18, 19-28.

Efford, M. G., Borchers, D. L., \& Byrom, A. (2009). Density estimation by spatially explicit capture-recapture: Likelihood-based methods. In D. L. Thomson, E. G. Cooch, \& M. J. Conroy (Eds.), Modeling demographic processes in marked populations (pp. 255-269). New York: Springer US.

Harris, D. B., \& Macdonald, D. W. (2007). Interference competition between introduced black rats and endemic Galápagos rice rats. Ecology, 88, 2330-2344.

Hooker, S., \& Innes, J. (1995). Ranging behaviour of forest-dwelling ship rats, Rattus rattus, and effects of poisoning with brodifacoum. New Zealand Journal of Zoology, 22, 291-304.

Horne, J. S., \& Garton, E. O. (2006). Selecting the best home range model: An information-theoretic approach. Ecology, 87, 1146-1152.

Howald, G., Donlan, C. J., Galvan, J. P., Russell, J. C., Parkes, J., Samaniego, A., et al. (2007). Invasive rodent eradication on islands. Conservation Biology, 21, 1258-1268.

Innes, J. G., \& Skipworth, J. P. (1983). Home ranges of ship rats in a small New Zealand forest as revealed by trapping and tracking. New Zealand Journal of Zoology, 10, 99-110.

Jones, H. P., Tershy, B. R., Zavaleta, E. S., Croll, D. A., Keitt, B. S., Finkelstein, M. E., et al. (2008). Severity of the effects of invasive rats on seabirds: A global review. Conservation Biology, $22,16-26$.

Low, B. W., Mills, H., Algar, D., \& Hamilton, N. (2013). Home ranges of introduced rats on Christmas Island: A pilot study. Ecological Management \& Restoration, 14, 41-46.

Morgan, D. R. (2004). Maximising the effectiveness of aerial 1080 control of possums (Trichosurus vulpecula) (Ph.D. Thesis). Lincoln University.

Morriss, G. A., Warburton, B., Cross, M. L., \& Nugent, G. (2011). Hoarding behavior by ship rats (Rattus rattus) in captivity and its relevance to the effectiveness of pest control operations. European Journal of Wildlife Research, 58, 483-488.

Peck, D. R., Faulquier, L., Pinet, P., Jaquemet, S., \& Le Corre, M. (2008). Feral cat diet and impact on sooty terns at Juan de Nova Island, Mozambique Channel. Animal Conservation, 11, 65-74.

Russell, J. C. (2011). Indirect effects of introduced predators on seabird islands. In C. P. H. Mulder, W. B. Anderson, D. R. Towns, \& P. J. Bellingham (Eds.), Seabird islands: Ecology, invasion, and restoration (pp. 261-279). New York: Oxford University Press.

Russell, J., Ringler, D., Trombini, A., \& Le Corre, M. (2011). The island syndrome and population dynamics of introduced rats. Oecologia, 167, 667-676.

Strauss, A., Solmsdorff, K. Y., Pech, R., \& Jacob, J. (2008). Rats on the run: Removal of alien terrestrial predators affects bush rat behaviour. Behavioral Ecology and Sociobiology, 62, 1551-1558.

Vieira, E. M., Iob, G., Briani, D. C., \& Palma, A. R. T. (2005). Microhabitat selection and daily movements of two rodents (Necromys lasiurus and Oryzomys scotti) in Brazilian Cerrado, as revealed by a spool-and-line device. Mammalian Biology, 70, 359-365.

Wegmann, A., Buckelew, S., Howald, G., Helm, J., \& Swinnerton, K. (2011). Rat eradication campaigns on tropical islands: Novel challenges and possible solutions. In C. R. Veitch, M. N. Clout, \& D. R. Towns (Eds.), Island invasives: Eradication and management (pp. 239-243). Gland: IUCN. 